\title{
新型冠状病毒肺炎住院患者康复介入原则与策略
}

\author{
段周瑛 ${ }^{1}$, 陈文华 ${ }^{1,2^{*}}$, 周瑞娟 ${ }^{1}$, 盛逸澜 ${ }^{1}$, 何 霏 ${ }^{1}$, 李剑华 ${ }^{2}$ \\ 1 上海交通大学附属第一人民医院,上海 200080; \\ 2 上海杉达学院, 上海 201209 \\ *通信作者:陈文华,E-mail :chen.wh@163.com
}

收稿日期: 2020-03-16; 网络首发: 2020-03-20

基金项目:上海交通大学“交大之星”计划医工交叉研究基金(YG2019QNB38)

DOI : $10.3724 /$ SP.J.1329.2020.03002

开放科学 (资源服务) 标识码 $($ OSID) :

摘要 当前, 新型冠状病毒肺炎(COVID-19)疫情形势仍较严峻。基于传染性呼吸系统疾病的临床特点, 探 索性地论述 COVID-19 住院期康复介入的原则与策略, 以期为 COVID-19 及其他传染性呼吸系统疾病住院 期间如何安全、有效地开展康复治疗工作提供借鉴。预防、治疗、康复一体化是 COVID-19 康复介入的根本 依据, 在疾病急性期的病情稳定阶段, 康复介入越早, 预后越好。缺氧是所有 COVID-19住院患者面临的主 要临床问题, 通过康复医学的系统管理手段安全有效地解决疾病导致的缺氧状态成为住院期康复最佳介入 点。基于此, 本研究提出 COVID-19 住院患者康复介入应多学科医疗团队合作, 以共同目标管理为导向, 把 握“不越位、不缺位”原则, 应用“节能减排”康复策略, 以一系列身一心层面的维稳、放松、降耗作为主要手段, 同时评估、干预个体与环境的交互作用, 将 COVID-19 的防控要求纳入康复管理过程。COVID-19住院患 者的康复介入不仅是技术介入, 更是一个系统管理的过程。以系统观的视角选择增进健康效益的手段, 体现 了康复医学中最重要的“以人为本”理念, 意识到康复医学多元化的内涵并加以运用, 将为康复治疗工作者 提供新的思路。

关键词 新型冠状病毒肺炎;传染性呼吸系统疾病;康复; 系统管理;作业治疗

新型冠状病毒肺炎(Corona Virus Disease 2019, COVID-19) 在全国及世界各地爆发并迅速传播。截 至2020年 3 月 11 日,我国住院确诊人数仍有 14831 例, 其中重症患者 4257 例 ${ }^{[1]}$ 。3 月 11 日,世界卫生 组织宣布该病呈全球“大流行”特征 ${ }^{[2]}$, 境外输入性 病例相关疫情同样严峻。随着对疾病认识的加深和 临床救治经验的积累,COVID-19 住院患者的康复 介人亦在努力探索中。本文基于传染性呼吸系统疾 病的临床特点,探索性地论述 COVID-19 住院期康 复介人的原则与策略, 以期为 COVID-19 及其他传 染性呼吸系统疾病住院期间如何安全、有效地开展 康复治疗工作提供借鉴。

\section{COVID-19 住院期康复介入的临床基础}

\section{1 “防、治、康”结合是康复介入的根本依据}

随着现代康复理念的不断普及, 疾病预防、治
疗、康复一体化已成为医疗界共识。相关研究表明 在疾病急性期的病情稳定阶段, 康复介人越早则预 后越好 ${ }^{[3]}$ 。

根据《国际功能、残疾和健康分类》(International Classification of Functioning, Disability, and Health, ICF) 的理论指导, 疾病导致的功能障碍与临床特点 紧密联系。在康复介入时既要考虑 COVID-19 作为 呼吸系统疾病的共性, 又需考虑其作为急性传染病 的特性, 更要考量彼此间的联系。COVID-19 作为纳 人甲类传染病管理的疾病, 疫情防控与病情控制密 切相关 ${ }^{[4]}$, 防控过程亦是一种环境评估和干预。康复 医学注重人与环境的交互作用, 从而解决身体结构 与功能、活动与参与等方面问题,如心理障碍、行为 失调、日常生活及活动能力下降等。因此,COVID-19 住院患者的康复不仅是技术介人, 更是一个系统管 理的过程, 对疾病生理状态、环境等要素的综合考

引用格式:段周暎,陈文华,周瑞娟,等. 新型冠状病毒肺资住院患者康复介人原则与策略 $[\mathrm{J}]$. 康复学报, 2020,30(3):173-176.

DUAN Z Y, CHEN W H, ZHOU R J, et al. Principle and strategy of rehabilitation intervention for inpatients with COVID-19 [J]. Rehabilitation Medicine, $2020,30(3): 173-176$.

DOI: $10.3724 /$ SP.J.1329.2020.03002 
量是定位康复介人点的必要途径, 也是实施康复医 疗行为的重要依据。

\section{2 缺氧为住院患者主要临床问题}

COVID-19 患者以发热、之力、干咳等为主要表 现,亦有伴鼻塞流涕、咽痛、肌痛和腹泻者 ${ }^{[5]}$ 。部分患 者多在发病 1 周后出现呼吸困难和/或低氧血症, 严重者快速进展为急性呼吸莬迫综合征 (acute respiratory distress syndrome, ARDS)、脓毒症休克、难 以纠正的代谢性酸中毒和出凝血功能障碍及多器 官功能衰竭等 ${ }^{[6]}$ 。一项有关住院 COVID-19 患者的 早期小样本量研究显示,一半以上确诊患者发展为 呼吸困难, 从发病到呼吸困难的中位持续时间为 8.0 $\mathrm{d} ; 29 \%$ 的患者出现 ARDS $^{[7]}$ 。COVID-19 死亡患者P 体穿刺取样获得的组织局部病理学研究提示, COVID-19病理特征与严重急性呼吸综合征 (severe acute respiratorysyndrome, SARS) 和中东呼吸综合征 (middle east respiratory syndrom, MERS) 的病理特征 非常类似, 主要引起深部气道和肺泡损伤为特征的 炎性反应 ${ }^{[8]}$ 。SARS 在临床上表现为进行性呼吸困难 与紫细、肺顺应性显著降低和氧治疗无效的动脉低 氧血症, 这些符合全身炎症反应综合征 (systemic inflammatory response syndrome,SIRS) 的表现 ${ }^{[9]}$ 。由 此可见, 对于此类急性传染性呼吸系统疾病, 病毒 是一种诱发因素, 触发的局部至全身非特异性炎症 反应及低氧血症是造成严重后果的关键原因,转归 过程主要与个体的免疫功能状态有关 ${ }^{[10]}$ 。

缺氧问题是所有住院 COVID-19 患者面临的 挑战。氧作为人体新陈代谢活动中的关键物质, 具 有维持免疫功能活力的作用, 是机体最重要的能源, 缺氧将导致缺少能量供给。即使是没有氧合功能障 碍的轻型、普通型患者, 对疾病认知不足、环境不适 应等产生的焦虑、失眠、烦躁等心理障碍均会增加 氧耗 ${ }^{[11]}$; 此外, 急性传染性呼吸系统疾病的快速变 化特征也存在向缺氧加重进展的风险。根据国家卫 健委发布的《新型冠状病毒肺炎诊疗方案(试行第 七版) 》 $\rangle^{[2]}$ 及上海市 COVID-19 临床救治专家组制定 的《上海市 2019 冠状病毒病综合救治专家共识》 ${ }^{6]}$, 病情监测、对症支持、保护/支持器官功能仍是临床 救治的重点, 所有抗病毒药物的疗效有待于进一步 临床研究来评估。因此, 在尚无明确的特效治疗药 物或治愈措施的情况下, 通过康复医学的系统管理 手段安全有效地解决疾病导致的缺氧状态应成为 住院期康复的最佳介人点。

\section{2 住院期康复介入原则与策略}

\section{1 “不越位, 不缺位”是康复介入的基本原则}

康复介入的主体是康复医学工作者。对住院患 者临床医疗仍是控制病情转归的重要手段,康复治
疗只能作为临床医疗的辅助措施。因此, 康复介人应 秉持“不越位,不缺位”的原则。目前尚无成熟的循证 证据提出具体的感染控制指标, COVID-19 患者住 院期康复介人“不越位”应是“不缺位”的必要条件。

\section{2 “节能减排”是康复介入的重要策略}

如何做到“不越位”与“不缺位”? 基于 COVID-19 的临床特点, 我们提出 “节能减排” 的康复策略, 将 治疗与管理结合, 在康复介人中重视机体自身的调 节 ${ }^{[13]}$ 。这样, 既能促进康复治疗与临床治疗相配合, 又能充分发挥康复医学的职能与作用。

\subsection{1 “节能”管理}

在缺氧且没有特效药物治疗的前提下,COVID-19 患者主要依靠自身免疫力来对抗疾病。因此, 需要 静养、放松、适应等待免疫, 帮助器官功能重建恢 复, 而 “节能”管理是最好办法。应对患者密切监测、 适时辅助, 避免过多的干预 (药物、器械不当使用) 和打扰等。

“节能” 管理的重点在于维稳、放松、降耗, 以减 少氧耗。主要措施包括但不限于以下几个方面: (1) 通过心理干预、疾病认知教育、放松训练等方式 改善恐惧、焦虑、烦躁等增加氧耗的心理状态; (2) 高 氧耗日常行为调整: 将个人生活习惯中所有活动行 为按降低氧耗的要求进行调整, 如合理布置环境、 管理体位、合理地使用工具和辅助具、日常生活秩 序化、活动中合理利用呼吸调控技术等以降低氧耗 ${ }^{[14]}$; (3) 适应性训练: 包括环境适应、医疗器械及用品 (口 罩、吸氧面罩) 适应性训练等, 减少因对陌生及隔离 环境生疏、医疗器械使用不适应、气管插管/面罩给 氧与辅助通气等医疗措施恐惧而产生不良高氧耗 情绪。

“节能”管理适用各个临床分型的确诊患者。即 使是轻症患者, 也面临着向重症转变的风险, 因此 需将维稳置于首位。现有研究显示, 轻症患者若向 治愈转归, 本身并不需过多物理治疗层面的干预, 此与 “节能” 管理的理念也相符合; 而重症患者往往 具有严重的氧合功能障碍, 此时, 维稳、放松、降耗 具有重要意义, 但不应排除在必要的时候进行以促 进排痰、提高呼吸肌功能为目标的呼吸训练 ${ }^{[15]}$ 。

\subsection{2 “减排”措施}

控制传染源、切断传播途径和保护易感人群是 COVID-19 防控的主要策略 ${ }^{[16]}$, “减排”即是将传染 性呼吸系统疾病的防控要求纳人康复治疗管理的 过程。它以住院患者 (传染源) 个体与环境的交互作 用为核心, 评估特定行为对整体住院环境防控风险 的影响, 设计符合防控要求、患者机体状态的康复 方案与干预流程, 同时建立有关预警应急机制 ${ }^{[17]}$ 。 具体 “减排”措施遵循 COVID-19 防控方案 ${ }^{[18]}$ 。 
“减排”本身其实与“节能”密切相关。根据物理 学定律, “节能”管理下的稳态会降低人体系统熵值, 即患者(传染源) 与环境间的物质交换减少, 从而达 到增进防控效果的目的。

\section{3 住院期“节能减排”康复策略的价值}

\section{1 临床-康复一体化团队工作模式下的目标管理}

中国康复医学会发布的《2019 新型冠状病毒 肺炎呼吸康复指导意见 (第二版)》中明确指出, COVID-19 康复介入必须取得医疗团队共识, 即令 治疗获益、过程安全、节省成本,并愿意提供协同。 临床与康复作为具有合作关系的一体化工作团 队 ${ }^{[19]}$, 应遵循共同的诊疗目标, 同时将诊疗目标分 工化、互补化实施, 此为目标管理的关键。“节能减 排”策略基于 COVID-19 的临床特点和防控要求, 对于临床诊疗可发挥支撑和补充作用，与临床-康 复多学科合作理念相契合, 充分体现了康复医学在 人体健康综合管理过程中的价值。

\section{2 作业治疗在 COVID-19康复治疗中的作用}

“节能减排”管理本质上属康复医学作业治疗 的范畴, 作业治疗的诸多内容均体现 “节能” 理 念 ${ }^{[20]}$ 。

3.2.1 教育观念干预 可减少不当认知导致的高氧 耗心理状态, 行为模式干预可通过秩序化降低氧耗。

3.2.2 放松技巧包括心理的放松和身体的放松， 两者互相关联。

3.2.3 能量节约技术/呼吸调控技术从日常生活 活动中 “节能”。

3.2.4 适时辅助利用治疗辅具、生存辅具和活动 辅具直接弥补受损的功能从而减少个体自身为了 获得功能而耗能。

3.2.5 适应性训练 与患者建立良好关系, 帮助其 融人 “态度”的环境; 帮助患者适应医疗器械/用品, 使其融人治疗的环境。 方式。

此外, “减排”亦可视作环境评估与干预的一种

患者的功能障碍可能关乎“身”, 可能关乎 “心”, 可能关乎身心之间的关系, 抑或关乎身心是否能和 谐地适应环境。作业治疗从身一心一环境交互层面产 生维持机体稳定的作用。有关急性肺损伤的研究显 示, 重症监护病房超早期的作业治疗干预可以改善

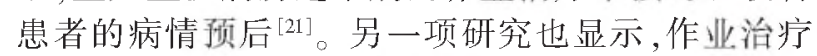
师对重症患者采取 “身心干预”, 患者的呼吸频率、血

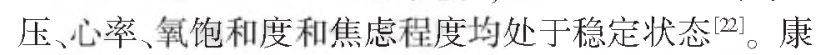
复不仅是通过训练使患者获得或恢复功能, 使功能 在环境中合理应用同样重要 ${ }^{[23-24]}$, 即作业治疗“赋 能”的重要理念。对于 COVID-19 患者而言, 作业治
疗是生存技巧的训练, 是对观念与行为模式的训练, 也是帮助患者最佳地融人环境的训练, 是康复治疗 中不可或缺的部分, 意识到康复医学多元化的内涵 并加以运用, 将为康复治疗工作者提供新的思路。

\section{4 小 结}

COVID-19 不同时期的康复介人应遵循不同原 则并采取不同策略 ${ }^{[3,25]}$ 。对于住院期, 康复介人需与 疾病的临床特点和防控要求密切结合。康复医学的 价值不只体现在技术层面, 更需理念层面的顶层设 计。康复介入的方法论与介人方法同样重要, 以系 统的管理视角选择增进健康效益的手段,正是康复 医学中最重要的 “以人为本” 理念的体现。本研究提 出的 “节能减排”管理模式和康复策略希望能为 COVID-19 患者康复介入提供新思路, 同时也迫切 希望随着未来循证科学证据和经验积累, 更加多样 化的康复治疗理念与技术将为 COVID-19 及其他 传染性呼吸系统疾病患者的功能恢复与重建带来 更多福音。

致谢: 复旦大学附属华山医院呼吸科专家金先 桥教授及上海援鄂抗疫感染科专家柴丽莉教授在 本文撰写过程中提供相关信息与帮助。

\section{参考文献}

［1］国家卫生健康委员会卫生应急办公室 (突发公共卫生事件应 急指挥中心). 截至 3 月 11 日 24 时新型冠状病毒肺炏疫情最 新情况 [EB/OL]. (2020-03-11)[2020-03-16]. http://www. nhc.gov.cn/xcs/yqtb/202003/37c1536b6655473f8c2120ebdc47 5731.shtml.

[2] WHO. WHO characterizes COVID-19 as a pandemic [EB/OL]. (2020-03-11) [2020-03-16]. http://www.xinhuanet.com/

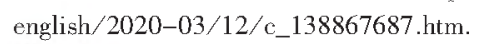

[3] 谢倽晓. 新型冠状病毒肺炎患者的康复治疗 [J]. 康复学报, $2020,30(1): 5-6$.

[4] 张奎兴. 呼吸道传染病的主要特点及预防控制办法 $[\mathrm{J}]$. 中国 医药指南, 2020,18(1):102-103.

[5] CHEN N, ZHOU M, DONG X, et al. Epidemiological and clinical characteristics of 99 cases of 2019 novel coronavirus pneumonia in Wuhan,China : a descriptive study [J]. Lancet, 2020, 395(10223): 507-513.

[6] 上海市新型冠状病毒病临床救治专家组. 上海市 2019 冠状 病毒病综合救治专家共识 $[J]$. 中华传染病杂志, 2020,38(3): 134-138.

[7] HUANG C, WANG Y, LI X, et al. Clinical features of patients infected with 2019 novel coronavirus in Wuhan, China [J]. Lancet, $2020,395(10223): 497-506$.

[8] XU Z, SHI L, WANG Y, et al. Pathological findings of COVID19 associated with acute respiratory distress syndrome $[\mathrm{J} / \mathrm{OL}]$. Lancet Respir Med, 2020, (2020-02-18) [2020-03-18]. https: $/ /$ www.sciencedirect.com/science/article/pii/S2213260020300 $76 \mathrm{X}$.

[9] MEO S A, ALHOWIKAN A M,AL-KHLAIWI T, et al. Novel coronavirus 2019-nCoV : prevalence, biological and clinical char- 
acteristics comparison with SARS $-\mathrm{CoV}$ and MERS $-\mathrm{CoV}[\mathrm{J}]$. Eur Rev Med Pharmacol Sci, 2020,24(4): 2012-2019.

[10] HON K L, LEUNG K K Y. Severe acute respiratory symptoms and suspected SARS again $2020[\mathrm{~J}]$. Hong Kong Med J,2020, $26(1): 78-79$.

[11] PIILGAARD H,LAURITZEN M. Persistent increase in oxygen consumption and impaired neurovascular coupling after spreading depression in rat neocortex $[\mathrm{J}]$. J Cereb Blood Flow Metab, $2009,29(9): 1517-1527$.

[12] 国家卫生健康委员会办公厅, 国家中医药管理局办公室. 新 型冠状病毒肺资诊疗方案 (试行第七版) [EB/OL]. (202003-03) [2020-03-16]. http://www.nhc.gov.cn/yzygj/s7653p/ 202003/46c9294a7dfe4cef80dc7f5912eb1989. shtml? spm =C735 44894212.P59511941341.0.0

[13] BECKERMAN H, BLIKMAN L J, HEINE M, et al. The effectiveness of aerobic training, cognitive behavioural therapy, and energy conservation management in treating MS-related fatigue: The design of the TREFAMS-ACE programme $[\mathrm{J}]$. Trials, 2013,14 (1) $: 250$

[14] DEMEYER H, BURTIN C, VAN REMOORTEL H, et al. Standardizing the analysis of physical activity in patients with COPD following a pulmonary rehabilitation program $[\mathrm{J}]$. Chest,2014, $146(2): 318-327$

[15]赵红梅,王辰。急/危重症早期呼吸康复研究进展 $[\mathrm{J}]$. 华西 医学, 2019,34(1):1-6.

[16]王玉波, 何勇. 新型冠状病毒肺炎刍识 $[\mathrm{J} / \mathrm{OL}$. 重庆医学: 14. (2020-02-21) [2020-03-16]. http://kns-cnki-net-http. cnki.shd1 .yuntsg.cn :2222/kcms/detail/50.1097.R.20200220. 2236.021.html.

[17]席家宁,公维军,姜宏英,等. 2019 冠状病毒病疫情下康复医 院防控策略专家共识(第一版) [J/OL]. 中国康复理论与实践, (2020-02-17) [2020-03-16]. http://kns-cnki-net-http.cnki.
shd1.yuntsg.cn:2222/kcms/detail/11.3759.R.20200216.1224.002. html.

[18] 国家卫生健康委员会办公厅. 新型冠状病毒肺炎防控方案 (第六版) [EB/OL]. (2020-03-07) [2020-03-16]. http://www. nhc.gov.cn/jkj/s3577/202003/4856d5b0458141fa9f376853224 d41d7.shtml.

[19] MULLER C, PLEWNIA A,BECKER S, et al. Expectations and requests regarding team training interventions to promote interdisciplinary collaboration in medical rehabilitation-A qualitative study [J]. BMC Med Edu,2015,15(1): 135 .

[20] MARTINSEN U, BENTZEN H, HOLTER M K, et al. The effect of occupational therapy in patients with chronic obstructive pulmonary disease: A randomized controlled trial $[\mathrm{J}]$. Scand J Occup Ther, 2017, 24(2):89-97.

[21] DINGLAS V D, COLANTUONI E, CIESLA N, et al. Occupational therapy for patients with acute lung injury : factors associated with time to first intervention in the intensive care unit $[\mathrm{J}]$. Am J Occup Ther, 2013, 67 (3):355-362.

[22] PROVANCHA-ROMEO A F, HOFFMAN A L, MALCOLM M $\mathrm{P}$, et al. Mind-body interventions utilized by an occupational therapist in a medical intensive care unit: An exploratory case study [J]. Work, 2019,63(2):191-197.

[23] CHAMBERLAIN E, TRUMAN J, SCALLAN S, et al. Occupational therapy in primary care: exploring the role of occupational therapy from a primary care perspective $[\mathrm{J}]$. Br J Gen Pract, $2019,69(688): 575-576$.

[24] D HALLE A, M MROZ T, J FOGELBERG D, et al. Occupational Therapy and Primary Care:Updates and Trends [J]. Am J Occup Ther, 2018,72(3):7203090010p1-7203090010p6.

[25] 中国康复医学会. 基于新型冠状病毒肺炎的呼吸道感染性疾 病疫情期间康复诊疗专家共识 $[\mathbf{J}]$. 中华物理医学与康复杂 志, 2020,42(2):97-101.

\title{
Principle and Strategy of Rehabilitation Intervention for Inpatients with COVID-19
}

DUAN Zhouying ${ }^{1}$, CHEN Wenhua ${ }^{1,2^{*}}$, ZHOU Ruijuan ${ }^{1}$, SHENG Yilan ${ }^{1}$, HE Fei ${ }^{1}$, LI Jianhua ${ }^{2}$

${ }^{1}$ Shanghai General Hosiptal, Shanghai Jiatong University, Shanghai 200080, China;

${ }^{2}$ Shanghai Sanda University, Shanghai 201209, China

* Correspondence:CHEN Wenhua, E-mail: chen.wh@163.com

\begin{abstract}
To provide references for safe and effective implementing rehabilitation treatment during hospitalization, in this article, we exploratively discusses the principle and strategy of treatment for inpatients with COVID-19 based on clinical characteristics as infectious pulmonary diseases. The foundation of rehabilitation intervention in COVID-19 is 'integration of prevention, treatment and rehabilitation' frame. The earlier the rehabilitation intervention starts, the better the prognosis will be, in the stable stage of the disease. Anoxia is the main clinical manifestation for inpatients with COVID-19. The best intervention point for inpatient's rehabilitation may be resolving the disease-caused anoxia via systemic management approaches safely and efficiently in rehabilitation medicine. Thus, this article proposes that we should keep on the principle, 'No Excess, No Absence', and use the strategy basing on 'Energy Conservation and Emission Reduction' as common goal management in the cooperation of multidisciplinary team approach on inpatient of COVID-19 rehabilitation. The series of stabilization, relaxation and energy-saving on 'physical-mental level' were the major methods. And meanwhile the interaction among evaluation and intervention on individual and environment at the same time with the inclusion of COVID-19 prevention and control will rule into rehabilitation management process. The rehabilitation intervention on COVID-19 inpatients is not only the technique-oriented but also a systemic management process. The option of health efficacy promotion approaches via systemic vision is the demonstration of the most important concept in rehabilitation medicine, 'People Frist of All'. The cognition on various meaning in rehabilitation medicine will provide new for rehabilitation field.
\end{abstract}

KEY WORDS COVID-19; infectious pulmonary disease; rehabilitation; systemic management; occupational therapy DOI: $10.3724 /$ SP.J. 1329.2020 .03002 